\title{
PENGARUH METODA PEMBERIAN BUMBU DAN JENIS IKAN TERHADAP MUTU DAN NILAI SENSORIK PADA IKAN AIR TAWAR ASAP
}

\section{The Effect of Spices Treatment Method and Kind of Fish To The Quality and Acceptance of Smoked Freshwater Fish}

Failisnur

Balai Riset dan Standardisasi Industri Padang

Jl. Raya LIK Ulu Gadut No. 23 Telp. (0751) 72201 Fax.(0751) 71320 Padang 25164

e-mail: failis@yahoo.co.id

Diterima : 17 September 2012, Revisi akhir: 14 November 2012

\begin{abstract}
ABSTRAK
Ikan merupakan bahan pangan yang bermutu tinggi terutama karena banyak mengandung protein, lemak, vitamin dan mineral yang sangat baik dan prospektif. Dalam penyimpanan, ikan mudah sekali mengalami kerusakan sehingga memerlukan upaya pengolahan diantaranya pengasapan. Mutu ikan asap sangat dipengaruhi oleh bahan baku, jenis bahan bakar, penyiapan proses, suhu dan lama pengasapan serta pengemasannya sehingga dihasilkan ikan asap dengan citarasa dan aroma yang khas. Penelitian dilakukan dengan perlakuan metoda pemberian bumbu yaitu menggunakan bumbu yang digiling dan perendaman dalam bumbu ekstrak serta perlakuan penggunaan jenis ikan air tawar yaitu ikan lele (Clarias gariepinus), mujair (Oreochromis mossambicus)dan nila (Oreochromis niloticus). Produk ikan asap kemudian dianalisis kandungan kimianya yang meliputi total fenol, kadar air, protein, lemak dan uji organoleptik rasa, tekstur dan aroma. Hasil penelitian menunjukkan bahwa perlakuan terbaik adalah perendaman dalam larutan bumbu ekstrak dan jenis ikan lele dimana dari hasil uji kimia didapatkan total fenol 45,05 ppm, kadar air $11,06 \%$, protein $66,65 \%$, dan lemak $5,87 \%$ serta uji organoleptik lebih disukai dengan nilai skala hedonik 4,$57 ; 4,50 ; 4,02$ dan 4,10 berturut-turut untuk rasa, tekstur, warna dan aroma.
\end{abstract}

Kata Kunci: Ikan asap, metoda pemberian bumbu, jenis ikan, mutu, nilai sensorik

\section{ABSTRACT}

Fish is a high quality food, especially because it contains a lot of protein, fat, vitamins and minerals that are very good and prospective for food source. However, it is highly perishable food in storage so that required treatment such process into smoked fish. Quality of smoked fish is strongly affected by raw materials, smoking material type, the preparation process, temperature and length of smoking and its packaging. So it was produced a smoked fish with a distinctive flavor and aroma. This study was conducted with the spices treatment method using ground spices and soaking in the extracts spices, and the treatment used a variety of freshwater fish those were lele (Clarias gariepinus), mujair (Oreochromis mossambicus), and nila (Oreochromis niloticus). Smoked fish products were then analyzed for total phenols, water content, protein, fat. Organoleptic test of taste, texture and aroma was also done. Test results showed that the best treatment was lele fish soaked in spices of extracts solution. The chemical tests were obtained total phenol; 45.05 ppm, water content; $11.06 \%$, protein; $66.65 \%$ and fat; $5.87 \%$ respectively. Furthermore the organoleptic test were preferred with hedonic scale 4.57; 4.50; 4.02 and 4.10 respectively for the taste, texture, color and aroma.

Key words: Smoked fish, method of spices treatment, kind of fish, quality, sensory values 


\section{PENDAHULUAN}

Sebagai bahan pangan, ikan merupakan sumber protein, lemak, vitamin, dan mineral yang sangat baik dan prospektif. Keunggulan utama protein ikan dibandingkan dengan produk lainnya adalah kelengkapan komposisi asam amino dan kemudahannya untuk dicerna. Mengingat besarnya peranan gizi bagi kesehatan, ikan merupakan pilihan tepat untuk asupan gizi di masa yang akan datang.

Hampir semua jenis ikan air tawar lebih aman dikonsumsi baik bagi anakanak maupun orang tua, karena ikan air tawar mengandung kolesterol relatif sedikit dibandingkan dengan ikan laut. Ikan air tawar dianjurkan untuk dikonsumsi dalam jumlah cukup, kandungan gizi ikan air tawar cukup tinggi dan hampir sama dengan ikan air laut. Tingginya kandungan protein dan vitamin membuat ikan air tawar ini sangat membantu pertumbuhan anakanak dan balita.

Kandungan air dan protein yang tinggi menyebabkan ikan tersebut cepat menjadi rusak (highly perishable food) sehingga memerlukan upaya pengolahan diantaranya pengasapan. Menurut Scert (2006), pengasapan memberikan nilai harga yang lebih baik jika dibandingkan dengan produk perikanan yang diolah dengan penggaraman atau pengeringan saja, selain itu warna dan flavor yang menarik dari produk hasil pengasapan dapat meningkatkan permintaannya di pasaran.

Pengasapan ikan merupakan penggabungan dari proses penggaraman, pengeringan, dan pemberian asap untuk mencegah kerusakan ikan. Menurut Adebowale et al. (2008) dan Lyhs (2002), pengasapan memiliki beberapa keuntungan yaitu memberikan efek pengawetan, mempengaruhi citarasa, memanfaatkan hasil tangkap yang berlebih ketika tangkapan berlimpah, memungkinkan ikan untuk disimpan ketika musim paceklik, meningkatkan ketersediaan protein bagi masyarakat sepanjang tahun, membuat ikan lebih mudah dikemas, diangkut dan dipasarkan, biaya cukup murah dan peralatannya sederhana.
Menurut Whittle dan Howgate (2000), langkah-langkah pada proses pengasapan akan berpengaruh terhadap kualitas produk akhir guna menentukan, mengendalikan dan mengukur atribut kualitas yang diperlukan pada produk. Ikan asap yang dihasilkan memiliki karakteristik warna, tekstur dan flavor yang khas (Martinez et al. 2007). Flavor merupakan salah satu karakteristik penting yang menentukan kualitas dan penerimaan produk tersebut di pasaran (Pratama, 2011). Penambahan bumbu bertujuan untuk menghambat pertumbuhan mikroba (Frazier, 1967 dalam Yohari, 1989) dan menimbulkan rasa dan flavor yang enak (Romans dan Ziegler dalam Yohari, 1989), sehingga dapat mengawetkan produk yang dibumbuinya.

Mutu ikan asap yang dihasilkan tergantung juga dari jenis ikan yang digunakan, karena perbedaan komposisi kimianya. Untuk itu perlu dilakukan penelitian pengaruh pemberian bumbu dan jenis ikan terhadap mutu dan tingkat penerimaan panelis dari ikan air tawar asap. Tujuan penelitian adalah untuk mendapatkan ikan asap dengan citarasa yang lebih disukai dan mutu yang lebih baik.

\section{METODOLOGI PENELITIAN}

\section{Bahan}

Bahan utama yang digunakan dalam Penelitian ini adalah ikan air tawar yaitu ikan lele, ikan mujair dan ikan nila segar. Bahan pembantu terdiri dari bumbu-bumbu tradisional berupa bawang putih, jahe, laos, ketumbar, cuka, daun salam, daun jeruk, sereh dan bahan kemasan serta bahan kimia pengujian.

\section{Alat}

Peralatan yang digunakan antara lain; pisau, waskom, talenan, gilingan bumbu, saringan, kuali, sendok pengaduk, oven pengasap, sealer dan peralatan pengujian.

\section{Rancangan Penelitian}

Rancangan penelitian adalah Rancangan Acak Lengkap (RAL) secara faktorial dengan perlakuan; cara pemberian 
bumbu (A) terdiri dari pemakaian bumbu giling (A1) dan pemakaian bumbu ekstrak (A2) yang difaktorkan dengan perlakuan jenis ikan (B) terdiri dari ikan Lele (B1), ikan Mujair (B2) dan ikan Nila (B3).

\section{Pelaksanaan Penelitian}

Ikan dibelah punggung dan dibersihkan dengan cara membuang kotoran isi perutnya, dicuci dan siap untuk dibumbui. Bumbu berupa bawang putih, jahe, laos, ketumba, cuka, daun salam, daun jeruk, dan sereh disiapkan melalui dua cara yaitu semua bumbu digiling sampai halus dan dilumurkan pada ikan (A1) atau semua bumbu direbus dengan air sampai mendidih lalu disaring dan filtratnya (ekstrak) digunakan untuk merendam ikan (A2). Pembumbuan dilakukan selama 1-2 jam kemudian diasap dalam oven pengasap dengan suhu rendah $40^{\circ} \mathrm{C} \pm 1$ jam (pengeringan), selanjutnya suhu dinaikkan menjadi $\pm 70^{\circ} \mathrm{C}$ sampai ikan berwarna kuning keemasan dan kecoklatan.

Pengeringan awal yang dilakukan pada pengasapan ikan berfungsi untuk mencegah penutupan lapisan luar ikan sebagai akibat dari pengerasan lapisan luar selama pengasapan. Ikan tidak akan mengering dengan sempurna selama pengasapan jika pengerasan terjadi karena kelembaban yang tertahan di dalam kulit ikan. Ikan yang telah melalui proses pengeringan sebelum pengasapan akan memiliki lapisan permukaan yang mengkilap (Berkel, 2004). Diagram alir pembuatan ikan asap adalah seperti Gambar 1.

\section{Analisis dan Pengamatan}

Analisis yang dilakukan terhadap ikan air tawar asap berupa analisis kimia total fenol menggunakan spektrofotometer, kadar air menggunakan metoda oven, kadar protein dengan metoda Kjedahl dan kadar lemak dengan menggunakan metoda Weibull, serta organoleptik rasa, tekstur, warna dan aroma. Untuk uji organoleptik terhadap 15 orang panelis menggunakan skala hedonik skala 1-5 dengan penilaian tidak suka, kurang suka, biasa, suka dan sangat suka.

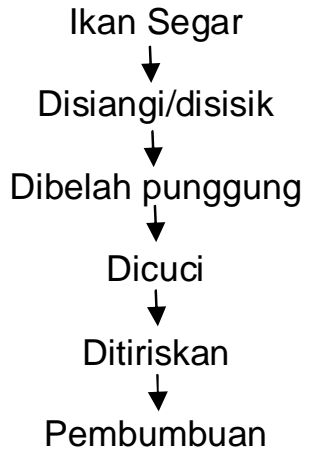

(bumbu giling atau bumbu ekstrak)

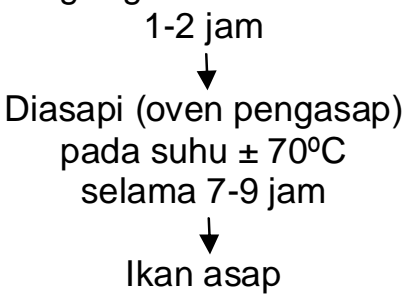

Gambar 1. Diagram alir pembuatan ikan air tawar asap.

\section{HASIL DAN PEMBAHASAN}

\section{Analisis Bahan Baku}

Hasil analisis kadar air, protein dan lemak dari ikan lele, ikan mujair dan ikan nila adalah seperti Tabel 1.

Tabel 1. Hasil analisa kadar air, protein dan lemak dari ikan segar

\begin{tabular}{|c|c|c|c|}
\hline Jenis Ikan & $\begin{array}{c}\text { K.Air } \\
(\%)\end{array}$ & $\begin{array}{c}\text { Protein } \\
(\%)\end{array}$ & $\begin{array}{c}\text { Lemak } \\
(\%)\end{array}$ \\
\hline Lele (B1) & 77,08 & 17,5 & 5,3 \\
Mujair (B2) & 76,6 & 16,9 & 3,0 \\
Nila (B3) & 76,8 & 17,7 & 3,1 \\
\hline
\end{tabular}

\section{Total Fenol}

Senyawa fenol dan turunannya banyak terkandung di dalam asap yang berasal dari kayu. Jumlah kadar fenol akan dipengaruhi oleh proses pengolahan seperti lamanya waktu pengasapan, komposisi asap, jarak sumber asap dengan bahan baku, ketebalan asap, jenis kayu dan kondisi pengasapan lainnya (Toth \& Potthast 1984 dalam Pratama (2011). Hasil analisis total fenol terhadap ikan air tawar asap seperti pada Gambar 2. 


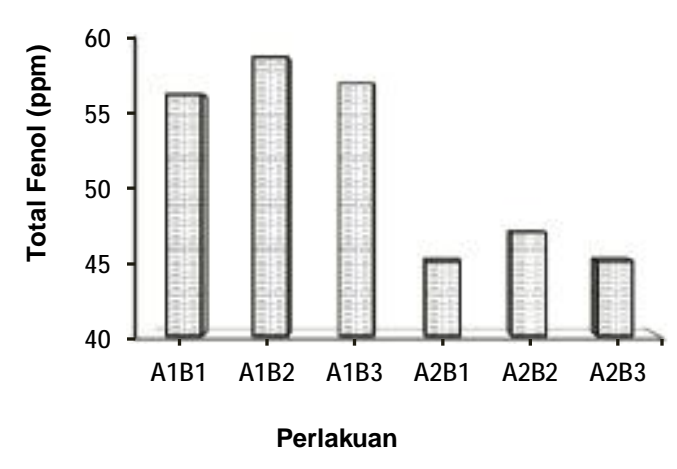

Gambar 2. Hasil Analisis total fenol ikan asap

Dari Gambar 2 terlihat bahwa pemakaian bumbu giling menghasilkan ikan asap dengan total fenol rata-rata yang lebih tinggi dibandingkan dengan pemakaian bumbu ekstrak. Pemakaian bumbu giling yang menempel pada permukaan ikan menyebabkan penguapan air dari tubuh ikan terhambat sehingga proses pengeringan lebih lama. Ikan dalam keadaan basah lebih banyak menyerap asap yang menyebabkan kandungan senyawa fenolnya menjadi lebih tinggi, sementara ikan yang memakai bumbu ekstrak lebih cepat mengering dan kandungan total fenolnya lebih rendah dibandingkan ikan berbumbu giling. Kandungan fenol produk dengan permukaan yang basah selama periode waktu yang sama ialah 20 kali lebih besar daripada produk yang kering. Komponen volatil lebih mudah diserap oleh asap dalam kelembaban yang lebih tinggi. Kebasahan kulit yang semakin tinggi akan menyebabkan semakin besarnya jumlah asap yang terserap (Toth \& Potthast 1984 dalam Pratama, 2011). Asap yang lembab akan membentuk lapisan kelembaban pada permukaan produk yang menyebabkan partikel asap menyerap lebih cepat (Berkel, 2004).

Penggunaan jenis ikan yang berbeda ternyata juga menghasilkan ikan asap dengan total fenol yang berbeda. Berdasarkan jenis ikan maka total fenol ikan asap tertinggi didapatkan pada ikan mujair dan terendah pada ikan lele. Menurut Maga (1987) dan Birkeland et al. (2007), ikan yang memiliki kandungan lemak yang lebih rendah mempunyai kemampuan menyerap asap yang lebih banyak sehingga kandungan total fenol pada produk tersebut lebih tinggi. Ikan lele dengan kadar lemak yang lebih tinggi dibandingkan dengan jenis ikan yang lain menghasilkan ikan asap dengan total fenol yang lebih rendah. Kandungan fenol dalam ikan asap yang semakin tinggi akan menyebabkan semakin lamanya masa simpan.

Permukaan ikan yang kering perlahan menunjukkan pengendapan asap yang lebih lambat selama pengasapan dibandingkan dengan permukaan yang basah, penyerapan fenol kurang maksimal. Fenol banyak terdapat di bagian permukaan ikan dibandingkan bagian dalam daging ikan yang diasapi. Komponen asap biasanya menempel pada permukaan ikan asap dan terakumulasi tidak lebih dalam dari $1 \mathrm{~mm}$ di bawah kulit selama penyimpanan (Lyhs, 2002). Daerah permukaan ikan yang semakin besar akan menyebabkan semakin besarnya jumlah partikel asap yang dapat diserap selama pengasapan. Produk asap juga menjadi lebih kering dengan baik sehingga tahan dalam penyimpanan (Berkel, 2004). Menurut Doe (1998), asap memiliki aktivitas antioksidan yang tinggi.

\section{Kadar Air}

Kadar air merupakan faktor penentu dari produk untuk menentukan apakah suatu produk dapat bertahan lama dalam penyimpanan. Menurut SNI 01-2725-1992 tentang Ikan Asap, kadar air maksimal ikan asap adalah $60 \%$. Hasil analisis kadar air dari ikan air tawar asap adalah seperti pada Gambar 3.

Kadar air ikan asap tertinggi diperoleh pada perlakuan pemakaian bumbu giling dengan jenis ikan lele (A1B1) yaitu 15,69\% dan terendah pada perlakuan pemakaian bumbu ekstrak dengan jenis ikan mujair (A2B2) yaitu 6,58\%. Tingginya kadar air pada pemakaian bumbu giling disebabkan karena bumbu giling yang melekat pada permukaan ikan sebelum diasap menyebabkan terhambatnya penguapan air dari tubuh ikan sewaktu pengasapan. Sedangkan kadar air yang tinggi pada ikan lele disebabkan karena kadar air awal ikan lele segar $(77,08 \%)$ yang lebih tinggi dibandingkan dengan ikan mujair $(76,6 \%)$ 
dan ikan nila (76,8\%). Menurut Pratama (2011), kadar air produk ikan asap akan dipengaruhi oleh kadar air awal bahan bakunya dalam hal ini kadar air jenis ikan yang digunakan.

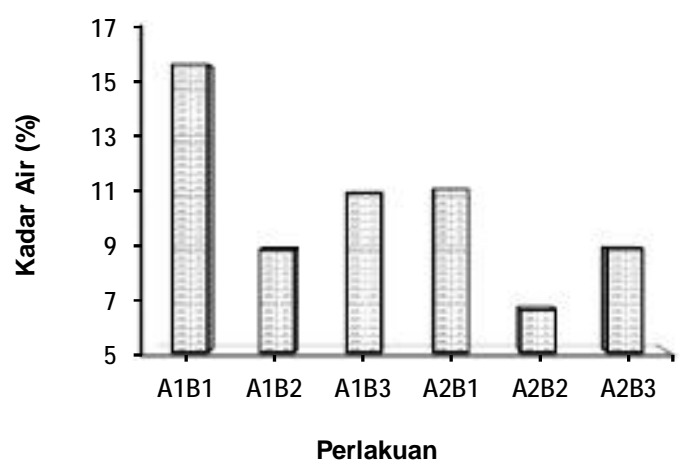

Gambar 3. Hasil Analisis kadar air ikan asap

Air pada ikan asap hilang karena adanya penguapan yang disebabkan oleh pengeringan di udara. Kehilangan air akan tergantung pada sifat permukaan dan bagian ikan yang terkena panas, waktu dan suhu pemanasan, serta laju dan kelembaban udara dan asap (Doe, 1998). Pengurangan kadar air akan mengakibatkan produk ikan asap menjadi awet dalam penyimpanan.

\section{Kadar Protein}

Hasil analisis kadar protein dari ikan air tawar asap adalah seperti pada Gambar 4. Kadar protein tertinggi terdapat pada perlakuan pemakaian bumbu giling dengan jenis ikan nila (A1B3) yaitu sebesar $68,0 \%$ yang berbeda nyata dengan perlakuan lainnya dan kadar protein terendah pada perlakuan pemakaian bumbu ekstrak dengan jenis ikan mujair yaitu sebesar 66,22\%. Rendahnya kadar protein pada pemakaian bumbu ekstrak kemungkinan karena ada sebahagian protein yang larut sewaktu proses perendaman ikan dengan larutan bumbu ekstrak pada suhu $\pm 40^{\circ} \mathrm{C}$ selama 1-2 jam.

Perbedaan kandungan protein juga disebabkan karena jenis ikan yang digunakan berbeda, dimana ikan nila segar mempunyai kadar protein lebih tinggi $(17,7 \%)$ dibandingkan dengan jenis ikan mujair $(16,9 \%)$ dan ikan lele $(17,5 \%)$.
Kandungan protein akan dipengaruhi oleh berbagai faktor yaitu faktor internal seperti jenis ikan, fase pertumbuhan, jenis kelamin dan lain sebagainya. Adanya perbedaan dalam nilai proksimat dapat disebabkan oleh adanya perbedaan jenis bahan baku.

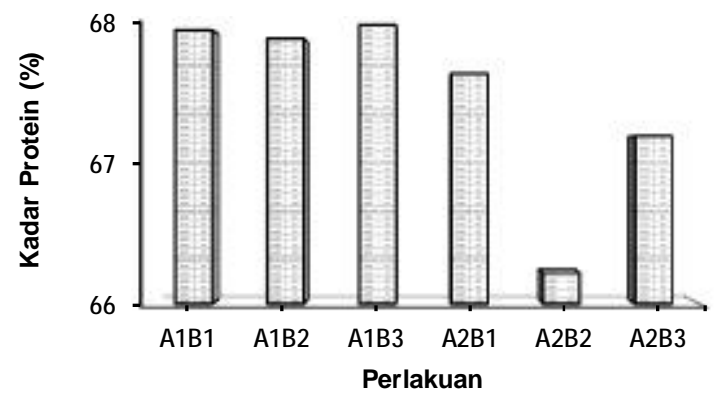

Gambar 4. Hasil Analisis kadar protein ikan asap

Pengasapan panas pada suhu tertentu akan mengakibatkan denaturasi dan degradasi protein serta menurunkan fungsi dari asam amino esensial. Hal ini bergantung pada jenis ikan dan protein yang terkandung di dalamnya (Kabahenda et al. 2009).

Senyawa fenol cenderung bereaksi dengan kelompok sulfhidril protein. Reaksi tersebut dapat mengakibatkan protein terdenaturasi dan menyebabkan turunnya nilai protein, agregasi protein dan pembentukan ikatan baru (Dwiari et al. 2008). Tinggi atau rendahnya nilai protein yang terukur dapat dipengaruhi oleh besarnya kandungan air yang hilang (dehidrasi) dari bahan.

\section{Kadar Lemak}

Kadar lemak dari ikan berpengaruh terhadap penetrasi bumbu sebelum pengasapan dan jumlah asap yang masuk ke dalam tubuh ikan selama berlansungnya proses pengasapan. Hasil analisis kadar lemak dari ikan air tawar asap adalah seperti pada Gambar 5.

Pada pemakaian bumbu giling dengan jenis ikan lele (A1B1) memberikan kandungan lemak tertingi (8,32\%) dan kadar lemak terendah pada pemakaian bumbu ekstrak dengan ikan mujair. Kandungan lemak dipengaruhi juga oleh metode pengolahan yang dilakukan 
(Birkeland et al. 2007) disamping pengaruh dari komposisi awal dari bahan baku.

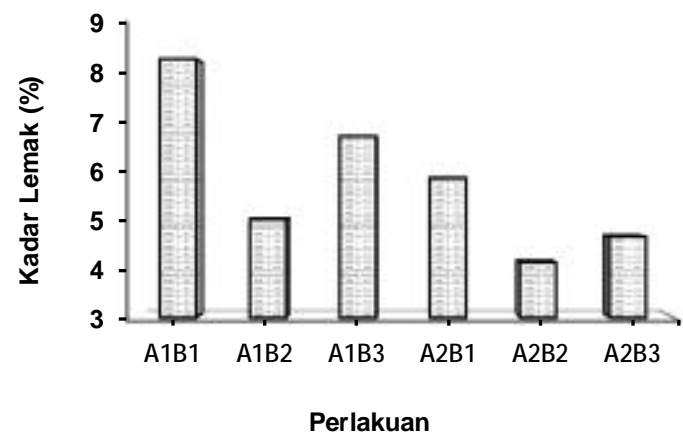

Gambar 5. Hasil Analisis kadar lemak ikan asap

Selama pengasapan berlangsung, kadar lemak dari ikan berangsur-angsur mencair terutama pada ikan lele yang mempunyai kadar lemak lebih tinggi dibandingkan dengan jenis ikan lainnya. Lemak dan air yang keluar dari ikan selama proses pengasapan menyebabkan terjadinya susut fisik (physical loss) lemak (termasuk asam lemak essensial) dan nutrisi mikro lainnya (Kabahenda et al. 2009). Bahan baku segar yang digunakan dalam pengasapan secara signifikan akan mempengaruhi hilangnya komponen nutrisi, semakin tidak berlemak ikan maka kehilangan lemak akan lebih tinggi (Espe et al. 2002). Ikan lele asap memiliki permukaan daging paling berminyak dan mengkilap dibandingkan dengan kedua jenis ikan asap lainnya. Hal ini menandakan bahwa ikan lele asap memiliki kandungan lemak yang lebih tinggi pada permukaan dagingnya.

Kandungan lemak pada ikan asap yang memakai bumbu ekstrak lebih rendah dibandingkan dengan pemakaian bumbu giling. Hal ini dikarenakan pada bumbu ekstrak sebahagian lemak sudah larut dalam air ekstrak yang bersuhu $\pm 40^{\circ} \mathrm{C}$, dan sewaktu pengasapan berlansung bumbu ektrak yang mempunyai ukuran pertikel lebih halus cepat mencairkan lemak yang ada pada ikan sedangkan pada bumbu giling karena ukuran partikel lebih besar dapat menghambat pencairan lemak dari tubuh ikan.

Lama pengasapan dapat mempengaruhi komposisi nutrisi ikan terutama kadar lemaknya. Suhu yang tinggi selama proses pengasapan ikan dapat menurunkan kadar asam lemak omega-3 ikan. Kandungan asam lemak tak jenuh yang tinggi pada ikan juga mengakibatkan ikan rentan terhadap proses oksidasi selama proses pengeringan dan pengasapan sehingga manfaat nutrisi yang berasal dari asam lemak ini menjadi berkurang (Doe, 1998).

Berkel (2004) menyatakan bahwa pengasapan panas menghasilkan produk dengan kandungan lemak yang rendah karena lemak akan meleleh keluar. Kehilangan kadar lemak dan air yang besar juga dapat terjadi karena denaturasi protein pada jaringan dalam tingkatan yang dapat menyebabkan penurunan daya ikat air dan sifat emulsifikasi protein.

\section{Uji Organoleptik}

\section{Rasa}

Komponen aktif rasa (taste-active) pada ikan diantaranya ialah asam amino bebas, peptida, asam-asam organik, basa ammonium kuartener dan mineral (Doe, 1998). Komponen-komponen ini juga sebagian besar berperan pada pembentukan rasa produk kering. Asam amino bebas merupakan senyawa ekstraktif berberat molekul rendah yang larut air dan merupakan penyumbang flavor utama pada produk perikanan. Terbentuknya asam amino bebas ini dipengaruhi oleh parameter pengasapan, penyimpanan, spesies ikan, kesegaran bahan baku sebelum pengeringan dan metode pengeringan yang digunakan. Hasil uji organoleptik rasa adalah seperti pada Gambar 6.

Perlakuan yang menghasilkan nilai sensorik rasa tertinggi adalah pemakaian bumbu ekstrak dengan jenis ikan lele (A2B1) dengan nilai rata-rata 4,57 (mendekati sangat disukai) dan yang paling tidak disukai panelis adalah pemakaian bumbu giling dengan jenis ikan mujair yang memberikan nilai 2,7. Pemakaian bumbu giling yang lebih lama mengering dalam proses pengasapan ternyata menyerap asap lebih banyak yang menyebabkan rasa ikan asap sedikit pahit (lebih berasa asap) sementara ikan dengan bumbu ekstrak 
yang terlebih dahulu mengering dalam proses pengeringan awal sebelum pengasapan menyebabkan terurainya protein menjadi asam amino lebih banyak. Proses autolisis atau reaksi lainnya pada daging ikan yang menyebabkan terurainya komponen-komponen yang mengandung nitrogen untuk menghasilkan asam amino bebas menyebabkan pembentukan rasa pada ikan asap (Motohiro, 1988).

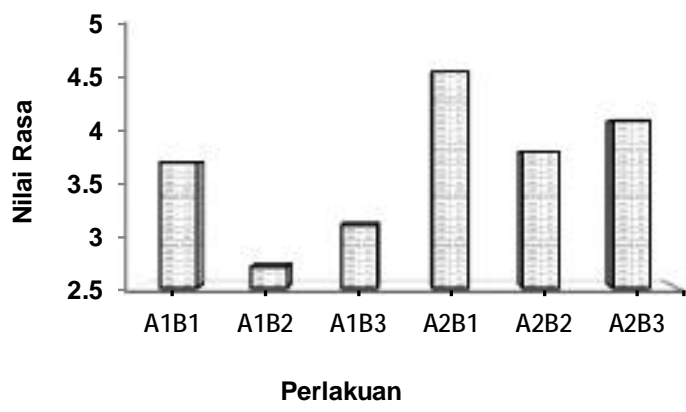

Gambar 6. Hasil uji organoleptik rasa dari ikan asap

Pemberian bumbu dan metoda yang digunakan memberikan citarasa yang berbeda pada ikan asap yang dihasilkan. Kecepatan penetrasi bumbu ke dalam daging ikan dipengaruhi oleh kesegaran ikan, jenis dan cara pembumbuan kering atau basah, dan konsentrasi lemak dari ikan. Ikan dengan lemak tinggi dapat menghambat penetrasi bumbu ke dalam daging ikan.

Rasa yang lebih gurih pada ikan lele dibandingkan dengan jenis ikan mujair dan nila adalah karena ikan lele mengandung asam glutamat dan glisin. Menurut Pratama (2011), kandungan asam glutamat pada ikan lele asap adalah sekitar 169,96 $\mathrm{mg} / \mathrm{kg}$. Asam glutamat berperan pada munculnya rasa umami; prolin pada rasa manis dan pahit; glisin dan alanin pada rasa manis, selain itu glisin dan alanin memiliki efek sinergis pada campuran senyawa yang mengandung asam glutamat (Kato et al. 1989 di dalam Wongso, 1998).

Menurut JICA (2008) dan Swastawati et al.(2007), rasa lezat yang menjadi ciri khas produk ikan yang diasap terutama berasal dari senyawa fenol dan aldehida. Rasa manis ditimbulkan oleh senyawa organik alifatik yang mengandung gugus $\mathrm{OH}$ seperti alkohol, beberapa asam amino, aldehida dan gliserol. Sumber rasa manis yang utama adalah gula atau sukrosa serta monosakarida dan disakarida lainnya (Winarno, 2008). Asam amino dan gula yang terdapat pada ikan asap kemungkinan mempengaruhi atribut sensoris manis yang terdeteksi oleh panelis pada ikan ini (Pratama, 2011).

Selain itu rasa manis dapat berasal dari proses pengolahan ikan asap yang melalui tahap proses perendaman bumbu dari berbagai macam rempah. Bumbu rempah ini akan mempengaruhi aroma dan rasa yang terdapat pada ikan asap. Rempah-rempah memiliki bahan dasar dari karbohidrat (termasuk gula, serat dan gum) (Brown 2009). Asam amino yang memiliki rasa manis yaitu glisin, alanin, serin, treonin dan prolindan dapat ikut mempengaruhi atribut rasa (Liu et al. 2009).

Rasa asap yang lezat disebabkan oleh reaksi asam, fenol dan komponen lainnya (Swastawati et al. 2007). Ikan lele asap memiliki intensitas rasa manis yang lebih tinggi. Kesan rasa manis dapat ditimbulkan oleh kandungan gula bebas yang terdapat dalam ikan, asam amino bebas seperti glisin, alanin, serin, treonin dan prolin, penambahan rempah-rempah yang dapat memberikan kesan rasa manis dan beberapa senyawa golongan fenol seperti dimetilfenol, 4-metilguiakol, guaiakol dan orto kresol (Pratama, 2011).

\section{Tekstur}

Hasil uji organoleptik tekstur adalah seperti pada Gambar 7. Tekstur ikan asap yang dihasilkan terlihat bahwa metoda pemberian bumbu dengan menggunakan bumbu ekstrak menghasilkan tekstur ikan asap yang lebih disukai dibandingkan dengan pemakaian bumbu giling. Perlakuan pemakaian bumbu ekstrak dan jenis ikan lele (A2B1) menghasilkan nilai organoleptik tertinggi yaitu 4.5, dimana tekstur daging ikan lele asap adalah padat, kering, liat, berkeping halus dan agak lembab.

Pembentukan tekstur ikan asap lebih banyak dipengaruhi oleh suhu dan lamanya pengasapan. Pengasapan dengan menggunakan suhu tinggi $\left(70-100^{\circ} \mathrm{C}\right)$ dengan waktu singkat akan menyebabkan 
ikan asap cepat mengering tetapi kadar air didalam tubuh ikan itu sendiri masih cukup tinggi karena penggunaan suhu tinggi di awal pengasapan menyebabkan mengerasnya lapisan luar tubuh ikan sehingga menghambat penguapan air dari tubuh ikan.

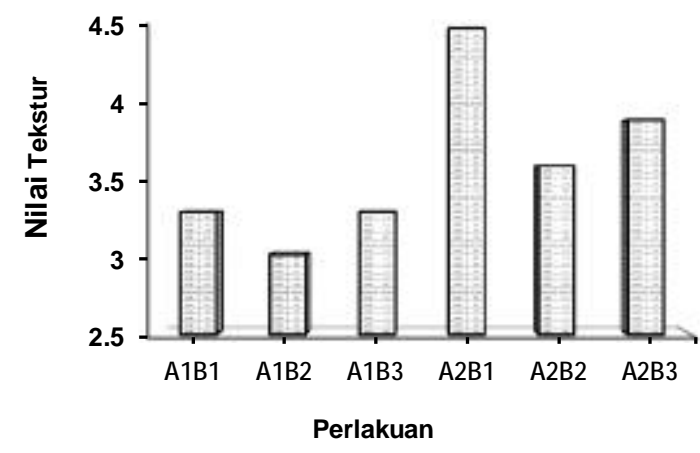

Gambar 7. Hasil uji organoleptik tekstur dari ikan asap

Jenis ikan yang digunakan juga akan mempengaruhi tekstur ikan asap yang dihasilkan. Ikan dengan kandungan lemak tinggi akan menghambat proses penguapan air sehingga teksturnya menjadi lebih lunak, agak liat, lembab dan mengkilap dibandingkan dengan ikan yang mempunyai kadar lemak rendah akan lebih kering, agak keras dan kurang mengkilap.

Suhu ruang pengasapan yang rendah akan menghasilkan asap yang ringan sehingga volume asap yang melekat pada ikan menjadi lebih banyak dan merata. Jika suhu ruang pengasapan tinggi, maka permukaan terluar tubuh ikan akan menjadi cepat kering dan mengeras, sehingga penguapan air terhalang dan proses pembusukan masih mungkin terjadi pada bagian dalam daging ikan. Pengasapan panas adalah proses dimana ikan diasapi dengan suhu paling tidak $70^{\circ} \mathrm{C}$ sehingga daging menjadi matang selain terkena asap. Lapisan protein larut garam yang disebut pellicle akan terbentuk pada permukaan daging selama proses. Pengasapan dingin dengan waktu yang lebih lama menyebabkan ikan menjadi keras, terutama sebagai akibat dari pengeringan yang dikenal sebagai hard smoking atau hard cure (Whittle \& Howgate, 2000).

\section{Warna}

Hasil uji organoleptik warna adalah seperti pada Gambar 8. Warna dari ikan asap yang paling disukai adalah pada pemakaian bumbu ekstrak dengan jenis ikan lele (A2B1) dengan nilai sensorik 4,02. Kandungan lemak ikan lele yang lebih tinggi menyebabkan lapisan permukaan dari ikan asap yang dihasilkan berwarna kuning keemasan sampai kecoklatan dan lebih mengkilap yang sangat disukai panelis.

Pengasapan dan pengeringan menyebabkan reaksi pencoklatan yang disebabkan oleh reaksi Maillard dan oksidasi lemak. Intensitas pencoklatan dipengaruhi oleh asam amino bebas, gula pereduksi, enzim proteolitik dan tahapan oksidasi lemak. Semakin banyak asam amino bebas maka pencoklatan yang terjadi akan semakin luas. Penampakan yang mengkilap dan rasa yang spesifik juga dipengaruhi oleh kandungan fenol dalam produk yang diasap (Pratama, 2011)

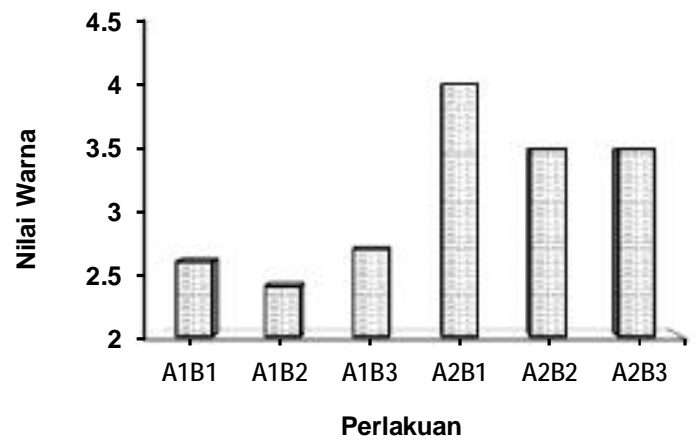

Gambar 8. Hasil uji organoleptik warna dari ikan asap

Warna coklat keemasan dari ikan asap disebabkan oleh reaksi dari fenol dengan oksigen dari udara. Guaiakol memberikan citarasa asap dan syringol berperan dalam pembentukan aroma. Warna dari ikan asap tidak hanya tergantung pada perubahan warna pigmen kulit tetapi juga dipengaruhi oleh jumlah dan komposisi komponen asap yang terserap serta interaksinya dengan produk selain itu jenis kayu yang digunakan sebagai sumber asap juga akan 
mempengaruhi warna dari produk pengasapan.

\section{Aroma}

Aroma merupakan salah satu faktor penting yang mempengaruhi penerimaan suatu produk olahan perikanan. Aroma pada ikan asap tidak hanya dipengaruhi oleh senyawa fenol tetapi komponenkomponen ekstraktif seperti asam amino bebas yang terkandung dalam produk perikanan juga akan berperan dalam pemberian citarasa produk (Pratama, 2011). Hasil uji organoleptik aroma adalah seperti pada Gambar 9.

Aroma ikan asap yang dihasilkan dari perlakuan pemberian bumbu dan jenis ikan menghasilkan nilai tertinggi pada perlakuan pemakaian bumbu giling dengan jenis ikan lele (A1B1) dengan nilai 4,8. Bumbu giling yang diuleni pada permukaan tubuh ikan memberikan aroma yang terakumulasi sempurna pada ikan, sedangkan perendaman dalam larutan bumbu ekstrak hanya sebahagian aroma yang menempel pada tubuh ikan dan sebahagian lagi tertinggal dalam larutan sisa. Menurut Brown (2009), minyak volatil dari rempahrempah mewakili aspek aromatik dan berkontribusi besar pada flavornya. Minyak nonvolatil (oleoresin) yang berasal dari jahe dan laos merupakan komponen flavor yang memberikan rempah-rempah kesan tajam menusuk, panas, manis atau pahit, sementara kandungan allicin dan allin pada bawang putih bersifat sebagai bakteriostatik yang efektif terhadap bakteri gram positif dan negatif (Yohari, 1989).

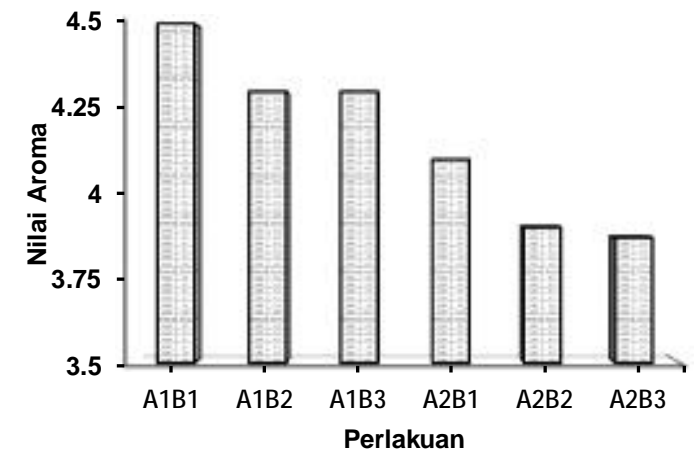

Gambar 9. Hasil analisa organoleptik aroma ikan asap.

\section{KESIMPULAN DAN SARAN}

\section{Kesimpulan}

Dari hasil penelitian pengaruh metoda pemberian bumbu dan jenis ikan terhadap mutu dan nilai sensorik ikan air tawar asap dapat disimpulkan sebagai berikut :

1. Perlakuan metode pemberian bumbu dengan cara digiling (A1) dan bumbu ekstrak (A2) dan jenis ikan air tawar yaitu lele (B1), mujair (B2) dan nila (B3) memberikan pengaruh yang berbeda nyata terhadap total fenol, kadar air, protein, lemak dan organoleptik rasa, tekstur, warna dan aroma ikan air tawar asap yang dihasilkan.

2. Perlakuan terbaik diperoleh pada pemakaian bumbu ekstrak dengan jenis ikan lele (A2B1) karena lebih disukai baik rasa, tekstur, warna dan aroma dengan nilai masing-masingnya adalah 4,57; 4,5; 4,02 dan 4,1 dengan total fenol 45,05 ppm, kadar air 11,06\%, protein $66,65 \%$ dan lemak $5,87 \%$.

\section{Saran}

Dari penelitian ini disarankan untuk dilakukan penelitian lanjutan lama dan suhu pengasapan pada tiap jenis ikan dalam meningkatkan mutu ikan asap.

\section{DAFTAR PUSTAKA}

Adebowale, B.A., Dongo L.N., Jayeola C.O., Orisajo S.B. 2008. Comparative quality assesment of fish (Clarias gariepinus) smoked with cocoa pod husk and three other different smoking material. J Food Technol. 6:5-8.

Berkel, B.M. van, Boogard B van de, Heijnen C. 2004. Preservation of fish and meat. Wageningen: Agromisa Foundation. $86 \mathrm{hlm}$.

Birkeland, S., Rora AMB., Skara T., Bjerkeng B. 2004. Effects of cold smoking procedures and raw material characteristics on product yield and quality parameters of cold smoked Atlantic salmon (Salmo salar L.) fillets. Food Research International. 37:273-286. 
Brown, JJ. 2009. Spices, seasonings and flavors. Di dalam: Tarte R, editor. Ingredients in Meat Products. New York: Springer Science. hlm 199210.41-52.

Doe, PE. 1998. Fish Drying and Smoking: Production and Quality. Pennsylvania: Technomic Publication. $245 \mathrm{hlm}$.

Dwiari, SR., Asadayanti DD, Nurhayati, Sofyaningsih M, Yudhanti SFAR; Yoga IBKW. 2008. Teknologi Pangan untuk Sekolah Menengah Kejuruan Jilid 1. Jakarta: Departemen Pendidikan Nasional. $285 \mathrm{hlm}$.

Espe, M, Nortvedt R, Lie O, Hafsteinsson H. 2002. Atlantic salmon (Salmo salar, $\mathrm{L})$ as raw material for the smoking industry. II: Effect of different smoking methods on losses of nutrients and on the oxidation of lipids. Food Chem. 77:41-46.

[JICA] Japan International Cooperation Agency. 2008. Bantuan teknis untuk industri ikan dan udang skala kecil dan menengah di Indonesia (teknik pasca panen dan produk perikanan) www.dkp.go.id/. Diakses15 Maret 2010.

Kabahenda, MK., Omony P., Husken SMC. 2009. Post-harvest handling of lowvalue fish products and threats to nutritional quality: a review of practices in the Lake Victoria region www.worldfishcenter.org. Diakses pada 3 Maret 2010.

Wongso, S, Yamanaka H. 1998. Extractive components of the adductor muscle of japanese baking scallop and changes during refrigerated storage. J Food Sci. 63:772-776.

Liu, JK., Zhao SM., Xiong SB. 2009. Influence of recooking on volatile and nonvolatile compounds found in silver carp Hypophthalmichthys molitrix. Fish Sci. 75:1067-1075.

Lyhs, U. 2002. Lactic acid bacteria associated with the spoilage of fish products [disertasi]. Helsinki: Department of Food and Environmental Hygiene Faculty of
Veterinary Medicine University of Helsinki.

Maga, JA. 1987. The flavor chemistry of wood smoke. Food Review

Martinez, O., Salmerón J., Guillén MD., Casas C. 2007. Sensorial and physicochemical characteristics of salmon (Salmo salar) treated by different smoking processes during storage. Food Science and Technology International. 13:477-484.

Motohiro T. 1988. Effect of smoking and drying on the nutritive value of fish: a review of Japanese studies. Di dalam: Burt JR. Fish Smoking and Drying. England: Elsevier Science Publishers Ltd. hlm 91-120.

Pratama, R.I. 2011. Karakteristik flavor beberapa jenis ikan asap di Indonesia. [Thesis] Pascasarjana IPB. Bogor.

[SCERT] State Council of Educational Research and Training. 2006. Fish Processing Technology Teachers' Sourcebook; Government Of Kerala Department of Education. Thiruvananthapuram.

Swastawati, F., Agustini TW., Darmanto YS., Dewi EN. 2007. Liquid smoke performance of lamtoro wood and corn cob. Journal of Coastal Development. 10:189-196.

Whittle, KJ., Howgate P. 2000. Glossary of Fish Technology Terms. Prepared under contract to the Fisheries Industries Division of the Food and Agriculture Organization of the United Nations [terhubung berkala]. http://www.onefish.org/. Diakses 4 Maret 2010.

Winarno, FG. 2008. Kimia Pangan dan Gizi. Bogor: M-Brio Press.286 hlm

Yohari, K. 1989. Mempelajari bentuk potongan ikan, suhu dan lama pengeringan serta penambahan kalium sorbat terhadap mutu dan keawetan dendeng ikan nila (Tilapia niloticus L) selama penyimpanan. [skripsi] Fakultas Pertanian IPB Bogor. 